\title{
Pawel Pałka
}

\section{Problem nauczania prawa Katolickich Kościołów Wschodnich w seminariach duchownych obrządku łacińskiego}

Prawo Kanoniczne : kwartalnik prawno-historyczny 20/3-4, 245-262

1977

Artykuł został zdigitalizowany i opracowany do udostępnienia w internecie przez Muzeum Historii Polski w ramach prac podejmowanych na rzecz zapewnienia otwartego, powszechnego i trwałego dostępu do polskiego dorobku naukowego i kulturalnego. Artykuł jest umieszczony w kolekcji cyfrowej bazhum.muzhp.pl, gromadzącej zawartość polskich czasopism humanistycznych i społecznych.

Tekst jest udostępniony do wykorzystania w ramach dozwolonego użytku. 
KS. PAWEE PAEKA

\section{PROBLEM NAUCZANIA PRAWA ISATOLICKICH KOSCIOLOW WSCHODNICH W SEMINARIACH DUCHOWNYCH OBRZĄDKU LACINSKIEGO}

Chociaż Kościół Katolicki pod względem wiary i dogmatów jest jednolity to pod względem liturgii i dyscypliny kościelnej przedstawia dość dużą rozmaitość. Różnice te dają się zauważyć nie tylko pomiędzy obrządkiem lacińskim i obrządkami wschodnimi, lecz także wśród samych obrządków wschodnich. W tym ostatnim wypadku jest to $\mathrm{w}$ dużym stopniu wynikiem odmiennego rozwoju prawa partykularnego, jakie w ciągu wieków kształtowalo się tu glównie na miejscowych synodach i mocą zarządzeń patriarchów różnych Kościolów Wschodnich oraz postanowień Stolicy Apostolskiej wydawanych dla poszczególnych obrządków wschodnich.

Katolickie Kościoły Wschodnie swoje odrębności dyscyplinarne, podobnie jak i liturgiczne, zachowują do chwili obecnej za pelną aprobata Stolicy Apostolskiej. Zagwarantowane im to bowiem zostało juz w chwili nawiązywania jedności ze Stolica Apostolską. Tak było np. przy zawieraniu unii z Grekami na soborze Liońskim II w 1274 r. 1 , i Florenckim 1439 r. ${ }^{2}$ oraz z Rusinami w czasie Unii Brzeskiej w $1595 \mathrm{rr}^{3}$. Taka gwarancje daje Katolickim Kościołom Wschodnim również sobór Watykański Ir. Ten ostatni czyni to zwłaszcza w Konstytucji o Liturgii Swiętej Sacrosanctum Concilium ${ }^{4}$ i Dekrecie o Kościolach Wschodnich Katolickich Orientalium Ecclesiarum ${ }^{5}$. Wyrazem woli Stolicy Apostolskiej zachowania odrębnej dyscypliny dla wiernych obrządku wschodniego jest również dokonana w ostatnim czasie kodyfikacja niektórych działów prawa Kościołów Wschodnich ${ }^{6}$. W wielu bowiem szczegółach podane $\mathrm{w}$ niej przepisy różnią się znacznie od obowiązujących $\mathrm{w}$ Kościele obrządku łacińskiego. Istniejących różnic w tym względzie nie usunie

1 Por. W. de Vries, Rom und die Patriarchate des Ostens, Freiburg-München 1963, s. 189-190.

2 Por. J. Haj jar, Les chrétiens uniates du Proche-Orient, Paris 1962 , s. 199; W. de V ries, dz. cyt., s. 192.

3 Bulla Klemens a VIII Magnus Dominus, 10 I 1595. Por. E. Lik ow ski, Unia Brzeska, Warszawa 1907, s. $133-137$.

4 Sacrosanctum Concilium, n. 4.

5 Orientalium Ecclesiarum, n. 2-6.

${ }_{6}$ Por. P. Pałka, Obecny stan kodyfikacji prawa dla Koscioza Wschodniego. „Roczniki Teologiczno-Kanoniczne” 8 (1961) z. 3, s. 57-59. 
zapowiedziana przez sobór Watykański II rewizja prawa kanonicznego ?. Swiadczy o tym już sam fakt ustanowienia specjalnej Komisji mającej przygotować Kodeks dla Kościolów Wschodnich zgodny $z$ duchem i tradycją tych Kościolów ${ }^{8}$.

Nasuwa się pytanie: czy jest rzeczą konieczna, aby kaplani obrządku lacińskiego znali $w$ jakimś stopniu również prawo Kościołów Wschodnich? Pytanie to nie dotyczy tych kapłanów, którzy odbywają studia na Wydziałach Prawa Kanonicznego, gdyż sam program tych studiów w dość dużym zakresie uwzględnia wykłady $z$ tego prawa. Nam chodzi - to, czy $w$ naszych seminariach duchownych alumni, jako przyszli duszpasterze, winni być zaznajamiani z tym prawem i ewentualnie w jakim zakresie?

Aby dać trafną odpowiedź na postawione pytanie należy uprzednio uświadomić sobie następujące dane:

1. Prawo Kościolów Wschodnich ma charakter nie tylko terytorialny lecz również personalny ${ }^{9}$ stąd też osoby obrządku wschodniego wiązane są tym prawem wszędzie gdziekolwiek by się one znajdowały, nawet wtedy gdy podlegają jurysdykcji ordynariuszów obrządku lacińskiego ${ }^{10}$.

2. Zamieszkanie wiernych obrządku wschodniego poza terenem własnego obrządku i korzystanie tam z posług religijnych kapłana obrządku łacińskiego nie powoduje zmiany ich obrządku ${ }^{11}$. W takich wypadkach osoby te nie tracą więc swego obrządku na skutek nawet dlugotrwałego przyjmowania Komunii św. lub odbywania spowiedzi w obcym obrząd$\mathrm{ku}^{12}$ podobnie jak i przez przyjęcie bierzmowania od szafarza obcego obrządku ${ }^{13}$. To samo należy powiedzieć również o przyjęciu z konieczności (ex necessitate) lub bezprawnie (fraude collatus) chrztu w innym obrządku niż tego domaga się prawo ${ }^{11}$. W tych wszystkich wypadkach osoby te prawnie należą nadal do obrządku wschodniego i wiązane sa prawem swego obrządku.

3. Dla należytego sprawowania duszpasterstwa przez kapłana obrządku łacińskiego nad wiernymi obrządku wschociniego bezwzględnie konieczna jest znajomość przynajmniej tych przepisów prawa Kościołów

7 Dekret o pasterskich zadaniach biskupów w Kościele, n. 44; Dekret - apostolstwie świeckich, n. 1.

8 Ustanowiona 10 VI 1975 nosi nazwę: Pontificia Commissione per la Revisione del Codice di Diritto Canonico Orientale. Por. Nuntia, Nr. 1, 1975 , s. 11.

9 Por. A. Coussa, Epitome praelectionum de iure ecclesiastico orientali, Cryptaeferratae 1948, I, s. 16.

10 Tamże, s. 16 - 17.

11 Taką zasade stawiał już B ened y kt XIV w Konst. Demandatum caelitus z 24 XII 1743. Fontes, I, n. 338, s. 801.

12 Kan. 98 § 5 (Skrót ,kan” oznacza kanony Kodeksu Prawa Kanonicznego $w$ odróżnieniu od kanonów zunifikowanego prawa obrządku wschodniego które oznaczane tu będą przez ,can".).

13 Orientalium Ecclesiarum, n. 14.

14 Kan. 98 § 1. 
Wschodnich, których zachowanie jest konieczne do ważności wykonywanych aktów prawnych. Przykładem tego moga być przepisy dotyczące zrywających przeszkód małżeńskich ${ }^{15}$ i formy prawnej zawarcia małżeństwa ${ }^{16}$, które nie we wszystkich szczegółach pokrywają się z prawem obrządku łacińskiego ${ }^{17}$ a które mają być zachowane równiez wtedy gdy wierni obrządku wschodniego zawierają małzeństwo wobec kapłana obrządku łacińskiego.

Biorąc pod uwage powyższe stwierdzenie oraz fakt istnienia na naszych terenach pewnej liczby osób obrządku wschodniego, zwłaszcza greko-katolickiego, będących $w$ zasięgu duszpasterstwa kapłanów obrządku łacińskiego, należy przyjąć, iż celowym jest aby alumni w naszych seminariach duchownych byli zaznajamiani również z prawem Kościolów Wschodnich. Jest to zresztą zgodne z myślą Stolicy Apostolskiej wyrażanej w ostatnich czasach przy różnych okazjach. Już Pius XI w encyklice Rerum Orientalium z 8 IX $1928 \mathrm{r}$. ubolewając nad słabą orientacją alumnów w zagadnieniach wschodnich dodaje: „Spodziewamy się, że nie będzie zbyt trudno utrzymać w każdym seminarium jednego profesora, który przy nauczaniu historii, liturgii lub prawa kanonicznego, mógłby wykładać przynajmniej podstawowe wiadomości z zakresu wschodnich zagadnień" ${ }^{18}$. W oparciu o tę zachętę kanoniści polscy zebrani na $\mathrm{V}$ Zjeździe Towarzystwa Teologów Polskich odbytym w Eodzi 1929 r. powzięli następującą rezolucję: „Stosownie do Encykliki Piusa XI r. 1928 Rerum Orientalium przy wykładach prawa kościelnego wschodniego należy również zwrócić uwagę na prawo partykularne tych narodów obrządku wschodniego, których wierni mieszkaja na terytorium państwa polskiego" ${ }^{19}$. Na VI Zjeździe tego Towarzystwa $1931 \mathrm{r}$. w Poznaniu na sekcji prawno-kanonicznej wysunięto wniosek, aby ,wykłady prawa wschodniego poświęcić w ciągu roku specjalne godziny, a nie traktować tylko dodatkowo na godzinach obrządku łacińskiego" 20. Chociaż te ostatnie sugestie nie zostały w czyn wprowadzone to jednak sama potrzeba poznania zagadnień wschodnich nadal jest aktualna. Przypomina to również wyraźnie sobór Watykański II w Dekrecie o Kościołach Katolickich zachęcając wszystkich,

15 Por. A. H e rm a n, De nova disciplina matrimoniali Ecclesiae Orientalis. Monitor Ecclesiasticus 75/1950/ s. 88-89.

${ }_{16}$ Por. P. Pałk a, Zwyczajna forma prawna zawarcia matżeństwa w nowym ustawodawstwie Katolickiego Kościoła Wschodniego. W: Pastori et Magistro. Praca Zbiorowa. Lublin 1966, s. 273-288.

17 Różnice te podane zostaną $w$ dalszych wywodach.

18 AAS 20 (1928) 9-11.

19 Pamiętnik Piatego Zjazdu $w$ Eodzi, Kielce 1929, s. 223. Wniosek zostal wysunięty po referacie ks. J. Bur a czewskiego na temat: Prawo Kosciola Wschodniego w wyktadach prawa kanonicznego (s. $238-254)$.

20 Pamiętnik Szóstego Zjazdu w Poznaniu, Kielce 1931, s. 225. Wniosek wysunięto po referacie ks. J. B u r'aczewskiego na temat: Prawo kXościoła Wschodniego w wykładach prawa kanonicznego (s. 238-254). 
mających częsty kontakt z urzędu lub apostolskiej posługi z wiernymiobrządku wschodniego, do poznania i szacunku obrzędów, karności, nauki i historiii oraz ducha tych wiernych ${ }^{21}$. Samym zaś duchownym tenże? Dekret przekazuje następujące zlecenie: „Wszyscy duchowni i asoby zdążające do święceń wyższych mają być należycie pouczani o ơbrządkach, a zwłaszcza wskazaniach praktycznych, odnoszących się do różnic między obrządkami. Owszem i świeckich należy pouczać w czasie: katechezy o obrządkach i odnośnych przepisach" 22. Ten nakaz odnosi się niewątpliwie $i$ do duchownych obrządku lacińskiego stąd też i oni mają pouczać świeckich zgodnie z tym zaleceniem soboru. Aby jednak mogli to czynić należycie uprzednio sami powinni być pouczani o tych: sprawach. Znajomość tego powinni zdobyć już w czasie przygotywywania się do święceń wyższych, a więc w czasie swych studíbw seminaryjnych.

W świetle powyższych wywodów sama konieczność zaznajamiania naszych alumnów z prawem Kościołów Wschodnich nie może budzić zastrzeżeń. Dyskutować można jedynie nad tym kiedy i w jakim zakresie ma to być czynione. Zrozumialą jest borviem rzeczą, że nie chodzi tu o podanie całośoi przepisów wschodnich, lecz tylko dotyczących niektórych zagadnień. Tych mianowicie których znajmość może przyczynić się do lepszego zrozumienia różnic dyscyplinarnych różnych obrządkach czy też może być pożyteczna lub konieczna dla kapłana sprawującego duszpasterstwo nad wiernymi obrządku wschodniego.

Wydaje się, że najkorzystniej byłoby nauczanie prawa Kościołów Wschodnich prowadzić równolegle z prawem obrządku łacińskiego. Gdyby nie można poświęcić na to oddzielnych godzin to przynajmniej przy odpowiednich kwestiach należaloby podkreślać różnice z prawem wschodnim. Stosowanie w tym wypadku metody porównawczej miałoby tę dodatnią stronę, że uniknęłoby się zbędnych powtarzań, a ponadto nie: uszczuplałoby się $i$ tak niewielkiej liczby godzin przeznaczonych na nauczanie prawa w naszych seminariach. Przy zastosowaniu takiej metody będzie dość okazji nawiązywania do prawa Kościolów Wschodnich zarówno przy interpretacji kanonów kodeksowych ${ }^{23}$ jak i później wydanych przepisów mających również oparcie w uchwałach soboru Watykańskiego II ${ }^{24}$.

${ }^{21}$ Orientalium Ecclesiarum, n. 6: „...Illi vero qui ratione sive muneris. sive apostolici ministerii frequens cum Orientalibus Ecclesiis aut cum earum fidelibus habeant commercium, in cognitione et cultu rituum disciplinae, doctrinae, historiae atque indolis Orientalim accurate, pro. gravitate officii quod gerunt, instituantur".

22 Tamże, n. 4.

${ }^{23}$ Do dyscypliny Kościoła Wschodniego nawiązują następujące kanony kodeksowe: $1,98,106,223,257,542$ n. $2,622 \S 4,756 \S 2,782 \S 5,804,881$. $\S 1,955 \& 2,1004,1099 \S 1$ n. 3, 2411.

${ }_{24}$ Chodzi tu zwlaszcza o takie dokumenty: Konstytucje $\mathrm{P}$ a wa VI Regimini Ecclesiae Universae z 15 VIII 1967 r. AAS 59/1967/657 i Motiw proprio Matrimonia mixta z 31 III 1970 r. AAS 62/1970/257/. 
Już przy omawianiu źródeł prawa kanonicznego należy podkreślić, że Kościoły Wschodnie dyscyplinę swoją - jak to bylo nadmienione: wyżej - opierają się w zasadzie na innych źródłach niż Kościół obrządku łacińskiego ${ }^{25}$. Wskazując te źródła winno się zwrócić uwagę zwłaszcza na zunifikowane $w$ latach 1949-1957 prawo małżeńskie ${ }^{26}$, procesowe ${ }^{27}$, zakonne i majątkowe ${ }^{28}$ oraz osobowe łącznie $z$ przepisami o obrządkach wschodnich ${ }^{29}$. Powinno się też tu zaznaczyć, że w $1972 \mathrm{r}$. powołano specjalną Komisję do rewizji tego prawa $i$ innych jego działów już opracowanych, lecz jeszcze nie promulgowanych ${ }^{\mathbf{3 0}}$.

Kanon $1 \mathrm{Kod}$. Prawa Kanonicznego, ustalający zasadę, że przepisy kodeksowe wiążą tylko wiernych obrządku łacińskiego, a wschodniego tylko wtedy gdy natura rzeczy tego się domaga ${ }^{31}$, daje okazję do bliższego wyjaśnienia pojęcia Kościoła Wschodniego i obrządków wschodnich zarówno $w$ znaczeniu liturgicznym jak i prawnym ${ }^{32}$. Tutaj też należałoby zaznaczyć, że pod względem godności wszystkie obrządki w Kościele są sobie równe, co też wyraźnie podkreśla sobór Watykański II $\mathrm{w}$ dekrecie o Katolickich Kościołach Wschodnich ${ }^{33}$. Zrozumiała jest tedy rzeczą, iż obrządek nie decyduje o precedencji osób w Kościele ${ }^{34}$.

W traktacie o prawie osobowym nadarza się dość często okazja do podkreślania różnic między prawem obrządku lacińskiego i wschodniego ogloszonego przez motu proprio Piusa XII Cleri sanctitati wiążącego wiernych obrządku wschodniego $z$ dniem 25 III 1958 r. ${ }^{35}$. Należałoby tu zwrócić uwagę zwlaszcza na następujące szczególy:

a) Chociaż prawo wschodnie, podobnie jalk i obrządku lacińskiego, nabycie własnego proboszcza i ordynariusza uzależnia od posiadania sta-

${ }_{25}$ Por. A. C o u s s a, dz. cyt. s. $41-197$.

${ }_{26}$ Motu proprio Pi us a XII Crebrae allatae sunt, 22 II 1949 (AAS. 41/1949/89-119).

${ }_{27}$ Motu proprio Pi u a XII Sollicitudinem nostram, 6 I 1950 (AAS $42 / 1950 / 5-120)$.

${ }_{28}$ Motu proprio Pi $\mathrm{i}$ a XII Postquam Apostolicis Litteris, 9 II 1952 (A.AS $44 / 1952 / 65-152$ ).

${ }_{29}$ Motu proprio Pi us a X.II Cleri sanctitati 2 VI 1957 (AAS 49/1957/ $433-603)$.

30 Zadania tej Komisji zostały określone w ten sposób: „Essa avra il compito di preparare, alla luce soprattutto dei decreti del Concilio Ecumenico Vaticano II, la riforma del "Codex Juris Canonici Orientalis" sia nello parti già publicate con quattro Motu Proprio (Crebrae allatae sunt, Sollicitudinem nostram, Postquam Apostolicis Litteris e Cleri: Sanctitati) sia nelle restanti parti, gia ultimate, ma non ancora publicate". Por. Nuntia, nr 1, 1975, s. 11.

${ }_{31}$ Por. G. Mich i els, Normae Generales Juris Canonici, ed. 2, I, Parisiis-Tornaci-Romae 1949, s. 38.

32 Por. A. J o u b i r, La notion canonique de rite, ed. 2, Romae 1961, s. $57-71$.

${ }^{33}$ Orientalium Ecclesiarum, n. 3.

34 Kan. 106 n. 4.

35 AAS 49 (1957) $433-603$. 
lego lub tymczasowego zamieszkania to jednak przyjmuje ono również inną możliwość w tym względzie, gdy prawo partykularne inaczej stanowi ${ }^{38}$. Ponadto na mocy prawa ogólnego dla wiernych obrządku wschodniego znajdujących się poza terenami wschodnimi ich ordynariuszem jest ordynariusz miejsca innego obrządku ${ }^{37}$. Może on wówczas, gdy ci wierni nie mają proboszcza własnego obrządku, wyznaczyć im duszpasterza innego obrządku z pełnymi prawami proboszczowskimi ${ }^{38}$. W naszych warunkach $z$ zasady będzie to proboszcz obrządku lacińskiego otrzymujący włađzę również nad wiernymi obrządku wschodniego.

b) W przeciwieństwie do kan. 96 KPK prawo Kościolów Wschodnich zatrzymuje nađal sposób obliczania pokrewieństwa według cywilnego prawa rzymskiego ${ }^{39}$. Przyjęcie $w$ tym wypadku komputacji rzymskiej powoduje różnicę $\mathrm{z}$ prawem kodeksowym w obliczaniu pokrewieństwa linii bocznej. Zwracając na to uwagę należy podkreślić, iż z tej racji zakres tej przeszkody małżeńskiej w Kościele Wschodnim nie zawsze pokrywa się z przyjętym w Kościele obrządku łacińskiego ${ }^{40}$.

c) Mimo iż prawo obrządku wschodniego ${ }^{41}$, podobnie jak i łacińskiego, za źródło przeszkody powinowactwa uznaje tylko ważnie zawarte małżeństwo to jednak $w$ Kościele obrządku wschodniego przeszkoda ta ma szerszy zakres. Obok bowiem powinowactwa ustalonego kanonem 97 KPK (krewni żony są powinowatymi męża, a krewni męża powinowaitymi żony) w Kościele Wschodnim przyjmuje się również, gdy prawo partykularne to uznaje ${ }^{42}$, porwinowactwo między krewnymi obu małżonków (affinitas ex digeneia secundi generis) oraz powinowactwo wywodzące się z zawarcia dwóch małżenstw przez osoby należące do trzech rodzin (affinitas ex trigeneia) ${ }^{43}$.

d) Kan. 98 KPK daje okazję do omówienia zasad regulujących przynależność do obrządku i jego zmianę. $Z$ konieczności nalézy tu uwzględnić nowe przepisy Kościoła Wschodniego De ritibus orientalibus ogłoszone W 1957 r. przez wspomniane wyżej motu proprio Piusa XII Cleri sanctitati 44. Przepisy te bowiem w pewnych szczegółach modyfikują postanowienia kan. 98 oraz podają bliższe dane związane ze zmianą obrządku, a w pewnych szczegółach wiążące nawet wiernych obrządku łacińskiego ${ }^{45}$.

Nowe przepisy ustalają przede wszystkim zasadę, iż chrzest decy-

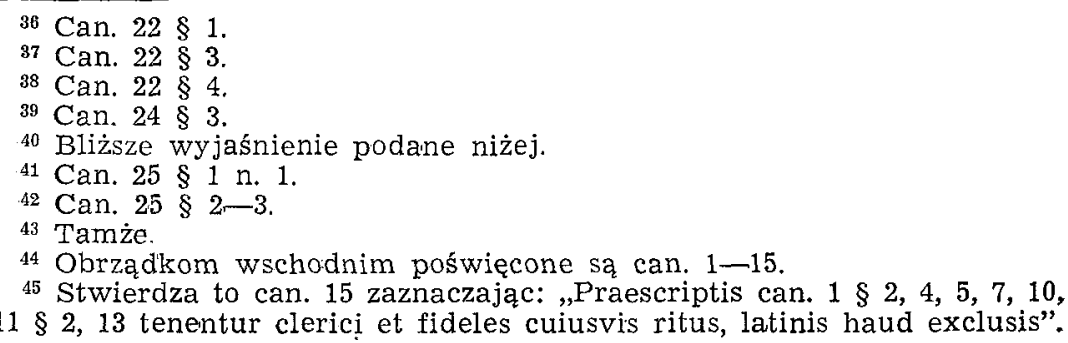


duje $w$ ogóle o przynależności do obrządku w jakim ktoś został ochrzczony, a nie wyłącznie tylko w obrząoku katolickim ${ }^{46}$, jak to stanowi kan. 98. Przy ustalaniu wyjątków od tej ogólnej zasady prawo Kościolów Wschodnich wymienia wypadek chrztu udzielonego z konieczności $w$ innym obrządku lub z racji podstępu oraz za zezwoleniem swego ordynariusza, gdy za tym przemawiała słuszna przyczyna ${ }^{47}$. Kan 98 w tym ostatnim przypadku wymaga dyspensy Stolicy Apostolskiej ${ }^{48}$. Nowe przepisy, podkreślając wyraźniej niż to czyni kan. 98 konieczność zezwolenia Stolicy Apostolskiej do ważności zmiany obrządku ${ }^{49}$, udzielają jednocześnie zezwolenia na taką zmianę niewiescie poślubiającej mężczyznę innego obrządku oraz - o czym nie wspomina cytowany 'Kanon - dzieciom niedojrzałym (impuberes) przy zmianie obrządku przez ich rodziców ${ }^{50}$. Przepisy nowe w kan. $11 \S 1$ zezwalały na zmianę obrządku również osobom ochrzczonym obrządku wschodniego wracającym do Kościoła Katolickiego ${ }^{51}$, lecz zezwolenie to odwołane zostało przez dekret soboru Watykańskiego II Orientalium Ecclesiarum ${ }^{52}$. Stąd też obecnie osoby te na zmiane swego rodzimego obrządku winny mieć również zezwolenie Stolicy Apostolskiej. Nowe przepisy bardziej zdecydowanie niż kan. 98 zakazują nakłaniania lub zachęcania do zmiany wlasnego obrządku, gdyż zabraniają tego czynić nie tylko osobom duchownym, lecz komukolwiek, a więc osobom swieckim i zakonnym ${ }^{53}$. Wreszcie przepisy te, czego nie czynił Kodeks Prawa Kanonicznego, stwierdzają iż uzyskany od Stolicy Apostolskiej reskrypt na zmianę obrządku sprowadza tę zmianę, gdy czego innego $w$ nim nie zaznaczono, dopiero wówczas gdy odbiorca reskryptu wobec ordynariusza miejsca lub proboszcza czy kapłana delegowanego i dwóch świadków złoży oświadczenie, iż przyjmuje nowy obrządek. Oświadczenie to winno być niezwiocznie wpisane przez proboszcza do księgi chrztów nowo przyjętego obrządku. Proboszcz ponadto ma obowiązek o tej zmianie powiadomić proboszcza tej parafii gdzie zmieniający obrządek był ochrzczony, aby na marginesie aktu chrztu była uczyniona odpowiednia wzmianka ${ }^{54}$.

e) Przy omawianiu obowiązków osób duchownych należalolby wspom-

46 Can. $6 \S 1$.

47 Can. $6 \$ 2$.

48 Por. P. Pałk a, Przynależność do obrzadku $i$ jego zmiana w suietle nowych przepisów Kościoła. Roczniki Teologiczno-Kanoniczne 10 (1963) z. 4 s. 83.

49 Can. 8 \& 1: Nemo potest sine licentia Sedis Apostolicae ad alium ritum valide transire, aut, post legitimum transitum ad pristinum rever.ti.

50 Can. 10: „Si ad ritum alium legitime transeat pater aut, in mixto matrimonio, mater catholica, filii impuberes, ad eundem ritum, ipso iure, itranseunt.

51 Por. W. Bassett, The Determination of Rite, Roma 1967, s. 223.

52 n. 4 , por. W. B a s s ett t, dz. cyt. s. $225-226$.

53 Can. 7: Nemo quemvis fidelem, ad alium ritum asumendum, ullo modo inducere praesumat.

54 Can. 13. 
nieć, iż nie we wszystkich Kościołach Wschodnich Katolickich duchowni zobowiązani są do zachowania celibatu. Lecz i w tych Kościolach posiadający subdiakonat lub wyższe święcenia niezdolni są już do zawarcia ważnego związku małżeńskiego ${ }^{55}$. Naleźy tu też zaznaczyć, że zarówno motu proprio Piusa XII Cleri sanctitati z 1957 r. ${ }^{56}$ jak dekret soboru Watykańskiego II Presbiterorum ordinis ${ }^{57}$, oraz encyklika $\mathrm{Pa}$ wła VI Sacerdotalis caelibatus z 1967 r. ${ }^{58}$ nic nie zmieniaja $w$ tym względzie $w$ dotychczasowej dyscyplinie Kościoła Wschodniego.

f) Omawiając różne dykasterie Kurii Rzymskiej w świetle Konstytucji Pawła VI Regimini Ecclesiae Universae z 1967 r. ${ }^{59}$ należy równiė̇ dokładnie naświetlić rolę Kongregacji dla Kościolów Wschodnich wskazując na jej kompetencje zwłaszcza w tzw. sprawach mieszanych, gdzie w grę wchodzą również osoby obrządku łacińskiego ${ }^{60}$.

g) W traktacie o osobach należałoby wreszcie zwrócić uwagę również na patriarchów podkreślając ich wiolkie znaczenie w Kościele Wschodnim oraz prawny stosunek do papieża ${ }^{61}$.

Poza wypadkami tu wskazanymi wykładowca ma częstszą okazję nawiązywania do prawa Koscioła Wschodniego również w traktacie De sacramentis, zwłaszcza przy omawianiu prawa małżeńskiego.

a) W związku ze chrztem należałoby dokładnie wyjaśnić przepisy określające jakiego obrządku kapłan jest właściwym szafarzem tego sakramentu. Jest to ważne zwłaszcza dla terenów obrządkowo mieszanych, gdyż może to zapiebiec różym nieporozumieniom wśród duszpasterzy, a ponadto ułatwia ustalenie obrządku osób ochrzczonych przez kapłana innego obrządku niż to przewiduje prawo. W takim bowiem wypadku: decydującym jest nie obrządek kapłana udzielającego chrztu, lecz obrządek w jakim ktoś prawie winien być ochrzczony ${ }^{02}$, a mianowicie:

1. gdy oboje rodzice są jednego obrządku katolickiego dziecko ich. winno być ochrzczone $w$ obrządku rodziców.

2. Gdy oboje rodzice są katolikami różnych obrządków dziecko ma być ochrzczone $w$ obrządku ojca, chyba że przepisy specjalne stanowiłyby co innego.

3. jeżeli jedno tylko $z$ rodziców jest katolikiem wówczas decydującym jest obrządek strony katolickiej ${ }^{63}$.

\footnotetext{
55 Can. 70.

50 Can. 71.

57 Presbyterorum ordinis, n. 16.

58 AAS 59 (1967 672.

59 AAS 59 (1967) 885-928.

60 Por. P, P a k ka, Kompetencje Kongregacji dla Kościołów Wschodnich $w$ świetle ostatniej reformy Kurii Rzymskiej. Roczniki Teologiczno-Kanoniczne, 16 (1969) z. 5, s. 25-36.

61 Can. 216-314. Por. E. Prze k o p, Natura i charakterystyczne cechy jurysdykcji patriarszej $w$ świetle nowego prawa dla Katolickich Kościotów Wschodnich. Roczniki Teologiczno-Kanoniczne 20 (1973) z. 5, s. 81 .

${ }^{62}$ Por. W. B a s s e t t, dz. cyt. s. $172-174$.

$63 \mathrm{Kan} .756$.
} 
4. co do dzieci nieprawego pochodzenia (filii illegitimi) to według powszechnie przyjętego zdania autorów mają one być ochrzczone w obrządku matki katoliczki, gdy ona jest publicznie znaną. W obrządku ojca tylko wtedy mają być chrzczone, gdy ojciec takiego dziecka jest publicznie znany i formalnie dziecko uznaje za swoje ${ }^{44}$.

Zasady tu podane są tak wiążące, iż rodzice nie mogą wybierać dowolnie innego szafarza chrztu dla swego dziecka niż to przewiduje prawo ${ }^{65}$. Zrozumiałą jest jednak rzeczą, że gdy brak na danym terenie duszpasterza właściwego obrządku wówczas ex necessitate chrztu dokonuje kapłan innego obrząaku, co jednak nie pociąga za sobą zmiany przysługującego dziecku obrządku ${ }^{60}$.

b) Przy omawianiu sakramentu bierzmowania należałoby wspomnieć, że W Kościele Wschodnim bierzmowanie udzielane jest zwykle bezpośrednio po chrzcie ${ }^{67}$. Obecnie zgodnie $\mathrm{z}$ dekretem soboru Watykańskiego II Orientalium Ecclesiarum wszyscy kapłani obrządku wschodniego mogą ważnie bierzmować zarówno razem ze chrztem jak i niezależnie od niego wiernych wszystkich obrządków nie wyłączając nawet wiernych obrządku lacińskiego ${ }^{68}$. Do ważności udzielanego przez nich bierzmowania koniecznością jest rzeczą, aby używali przy tym krzyżma poświęconego przez biskupa lub patriarchę ${ }^{69}$. W myśl wyżej wspomnianego dekretu kapłani obrządku lacińskiego, mający władzę bierzmowania $w$ pewnych wypadkach lacinników, w tychże samych wypadkach moga ważnie bierzmować również wiernych obrządku wschodniego, a więc częściej niż to przewidywał dekret Kongregacji dla Kościoła Wschodniego De Sacramento Confirmationis z 1 V 1948 r. ${ }^{70}$. Godziwe udzielánie bierzmowania przez kapłana wiernym innego obrządku wymaga zawsze zachowania wydanych $w$ tym względzie przepisów prawa powszechnego i partykularnego. We wszystkich wypadkach udzielanie

64 Por. W. B a s s et, dz. cyt. s. 94-97.

65 AAS 11 (1919) 478: „Utrum qui ad praeces parentum, contra praescriptum canonis 756 , a ritu alieni ministro baptizati sunt, pertineant ad ritum in quo sunt baptizati, vel ad ritum in quo, iuxta praescriptum canonis 756 , baptizari debuissent. - Resp. Prout casu exponitur, negative ad primam partem, affirmative ad secundam".

60 Wynika to z kan. $98 \S 1$.

67 Por. B. E m m i, Introduzione alla teologia orientale, Roma 1958, s. 68.

68 Orientalium Ecclesiarum, n. 14: „Presbyteri omnes orientales hoc sacramentum, sive una cum Baptismo sive separatim, valide conferre possunt omnibus fidelibus cuiusvis ritus, latino haud excluso, servatis ad liceitatem praecriptis iuris tum communis tum particularis".

69 Tamże, n. 13: "Disciplina de ministro. S. Chrismatis inde ab antiquissimis temporibus apud Orientales vigens plene instauretur. Idcirco presbyteri hoc sacramentum conferre valent, adhibito Chrismate a patriarcha Nel episcopo benedicto".

70 Tamże, n. 14: „Presbyteri quoque latini ritus, secundum facultates quibus gaudent circa ministrationem huius sacramenti, valent illud etiam fidelibus Ecclesiarum Orientalium ministrare, sine praeiudicio ritui, servatis quoad liceitatem praescriptis iuris sive communis sive particularis. 
bierzmowania przez szafarza innego obrządku nie sprowadza zmiany obrządku osoby bierzmowanej ${ }^{71}$.

c) W związku z Eucharystią powinno się zaznaczyć, że:

1. w obrządkach wschodnich do Mszy św. używa się przeważnie chleba kwaszonego i że wierni mogą dowolnie komunikować w jakomkolwiek oforządku katolickim 72 .

2. każdy kapłan przy odwrawianiu Mszy św., podobnie jak i innych czynności liturgicznych, ma obowiązek przestrzegać ściśle przepisów własnego obrzadku i to nawet wtedy gdyby spelnial posługi wyłącznie dla wiernych innego obrza.dku ${ }^{73}$.

3. kapłani abrządku wschodniego nie mogą korzystać z przywileju udzielonego łacinnikom odprawiania 3 Mszy św. W Dzień Zaduszny. i w Boże Narodzenie ${ }^{74}$.

4. w koncelebrze mogą brać udział tylko kapłani jednego obrządku, gdyż inaczej byłoby to mieszanie obrządków wielokrotnie zakazywane przez Stolicę Apostolską. Sprzeciwiałoby się to również wspomnianej zasadzie, iż każdy kapłan przy sprawowaniu funkcji liturgicznych obowiązany jest do ścisłego przestrzegania przepisów własnego obrządku.

5. wierni czynią zadość obowiązkowi uczestniczenia we Mszy św. odprawianej w jakimkolwiek obrządku katolickim ${ }^{75}$. Prawo wschodnie zaleca jedynie, aby tam gdzie są różne obrządki wierni obrządku wschodniego uczęszczali na nabożeństwa do swych kościołów, zwłaszcza w niedziele i dni świąteczne ${ }^{76}$.

d) Interpretując kanony o sakramencie pokuty należy podkreślić, iż. wierni mogą dowolnie odbywać spowiedź przed kapłanem każdego obrządku katolickiego byle kapłan ten, mial potrzebną jurysdykcję od ordynariusza miejsca gdzie spowiedź się odbywa ${ }^{77}$. $\mathrm{Na}$ obszarach. wschodnich (regiones orientales) i terytoriach wschodnich (territoria ritus orientalis) ${ }^{78}$ kapłani obrządku wschodniego posiadający bez żadnych ograniczeń upoważnienie do słuchania spowiedzi od swego ordynariusza mogo spowiadać wiernych jakiegokolwiek obrzadku. Kapłani ci wiernych swego obrządku mogą spowiadać tam nawet $w$ miejscach należących wyłącznie do jednego obrządku, innego niż obrządek tych kaplanów, chyba że ordynariusz tych miejsc wyraźnie sprzeciwiłby się

71 Tamże.

72 Por. B. Emmi, dz. cyt. s. 17; A. Petrani, De relatione iuridica inter diversos ritus in Ecclesia Catholica, Taurini - Romae 1930, s. $85-86$.

${ }^{73}$ Wyraźnie podkreślają to kanony 816 i 851 oraz can. 2 Cleri sanctitati.

74 Por. A. Petrani, dz. cyt. s. 81.

75 Kan. 1249.

${ }^{76}$ Can. 2 \& 2: „Ubi plures sunt ritus, suadetur fidelibus ut proprii ritus ecclesias crebro, diebus praesertim dominicis et festis, adeant, ibique divinis adesse officiis non praetermittant".

77 Kan. 905.

${ }_{78}$ Motu proprio Pius a XII Postquam Apostolicis Litteris $w$ can. 303 różnice między tymi terenami wyjaśnia $w$ ten sposób: $\S 1$ n. 2. 
temu ${ }^{79}$. Poza tymi obszarami i terytoriami kaplani obrządku wschodniego do słuchania spowiedzi, nawet wiernych swego obrządku, muszą mieć jurysdykcję od ordynariusza miejsca obrządku lacińskiego.

e) Przy omawianiu święceń kapłańskich należałoby zaznaczyć że motu proprio Pawia VI Ministeria quaedam z 15 VIII 1972 r. wprowadzające reformę święceń niższych i znoszące subdiakonat nie dotyczy Kościołów Wschodnich ${ }^{80}$. Stąd też Kościoły te nadal zatrzymują swój stan dotychczasowy z tym, że subdiakonat nadal stanowi tu zrywająca przeszkodę małżeńską ${ }^{81}$. W Kościołach Wschodnich nie wymagających zachowania celibatu duchowni moga zawierać małżeństwo tylko przed przyjęciem diakonatu względnie subdiakonatu, gdy to ostatnie swięcenie W danym Kościele jest znane ${ }^{82}$. W Kościołach Wschodnich biskup nigdy nie może być związany węzłem małżeńskim ${ }^{83}$ podobnie jak i jego wikariusz generalny (syncellus) od którego prawo wymaga też zachowania celibatu ${ }^{84}$.

f) Chociaż zalecane jest, aby sakrament chorych był udzielany przez proboszcza tego samego obrządku co chory to jednak $\mathrm{w}$ razie konieczności może go udzielać godziwie również kapłan innego obrządku ${ }^{85}$. Według dyscypliny obrządku wschodniego olej chorych poświęca każdorazowo kapłan przy udzielaniu tego sakramentu nawet osobie obrządku łacińskiego ${ }^{86}$. Kaplan zaś obrządku lacińskiego zawsze ma używać o:eju poświęconego przez biskupa chyba, że samo prawo powszechne lub indult apostolski czy też nagląca konieczność upoważnia go do poświęcenia tego oleju ${ }^{87}$.

g) W traktacie o sakramentach należy zwrócić uwagę szczególną na różnice zachodzące między prawem małżeńskim obrządku lacińskiego i wschodniego. W pewnych bowiem wypadkach od przestrzegania tych różnic uzależniona jest ważność małżeństw osáb obrządku wschodiniego zawieranych wobec kaplana obrządku łacińskiego. Odnośnie przepisy prawa małżeńskiego Kościołów Wschodnich, ogloszone w 1949 r. przez motu proprio Piusa XII Crebrae allatae sunt, wiążą wiernych obrządku

„Nomine regionum orientalium intelliguntur loca ommia, etsi jin eparchiam, provinciam, archiepiscopatum vel patriarchatum non erecta, in quibus orientalis ritus ab antiqua aetate servatur. $\S 1 \mathrm{n}$. 3. Territorium ritus orientalis significat loca in quibus erecta est saltem exarchia pro fidelibus ritus orientalis extra regiones orientales commorantibus".

79 Orientalium Ecclesiarum, n. 16.

80 AAS 64 (1972) 529-534.

81 Cleri sanctitati, can. 70 : „Subdiaconi omnesique clerici in maioribus ordinibus constituti ita a nuptiis arcentur ut, ad normam iuris, ad matrimonium contrahendum inhabiles sint".

82 Por. B. E m m i, dz. cyt. s. 17 .

83 Cleri sanctitati, can. 69: "Nullus ad episcopalem ordinem promoveri potest qui non sit caelebs vel a matrimonii vinculo legitime solutus".

84 Tamże, can. 433 § 1: Syncellus sit sacerdos coelebs e clero saeculari, annos natus non minus triginta..."

85 Por. A. Petrani, dz. cyt. s. 90.

86 Tamże.

87 Kan. 945 . 
wschodniego od 2 maja roku wspomnianego ${ }^{88}$. Wiążą one ich wszędzie gdziekolwiekby się znajdowali $i$ to nawet wtedy gdy podlegają ordynariuszowi obrządku łacińskiego ${ }^{89}$. Stąd też kapłan łaciński błogosławiący małżeństwa osób obrządku wschodniego lub zawierane z osobami abrządku łacińskiego winien należycie znać różnice między przepisami tych obrząqdków co niewątpliwie może znacznie zmniejszyć niebezpieczeństwo zawierania nieważnych małżeństw.

Wspomniane różnice są tu dość znacznie, a mianowicie:

A. Co do przeszkód małżeńskich. Prawo wschodnie obok przeszkód tamujących podanych $w$ Kodeksie Prawa Kanonicznego zna jeszcze przeszkodę opieki (tutela), gdy prawo cywilne na jakimś terenie ją przyjmuje ${ }^{90}$. Przeszkoda ta, podobnie jak przeszkoda pokrewieństwa prawnego z adopcji wypływająca, może być również przeszkodą zrywającą o ile prawo cywilne za taką ją uznaje. Co zaś dotyczy przeszkody plynącej ze ślubu prostego przyjęcia subdiakonatu lub święcenia wyższego to tylko $\mathrm{w}$ tych obrządkach wschodnich jest ona zaciągana, gdzie duchowni od przyjęcia tych święceń zobowiązani są do zachowania celibatu ${ }^{91}$.

Więcej różnic daje się tu zauważyć w dziale przeszkód zrywających. Chociaż bowiem w zasadzie rodzaj tych przeszkód jest taki sam jak W Kościele obrządku łacińskiego to jednak zachodzą pewne różnice $\mathrm{w}$ ich zakresie wywołane głównie innym sposobem obliczenia tych przeszkód.

1. W Kościele Wschodnim szerszy zakres ma przede wszystkim przeszkoda pokrewieństwa $w$ linii bocznej będąca tu przeszkodą zrywającą do szóstego stopnia włącznie według liczenia prawa rzymskiego ${ }^{02}$. Uwidacznia się to w 5 i 6 stopniu tej przeszkody przy dlugości szeregów 1-4, 2-4 i 1-5. W tych bowiem wypadkach zawarcie małżestwa w Kościele Wschodnim zakazane jest pod sankcją nieważności podczas gdy w Kościele obrządku lacińskiego takie pokrewieństwo nie stanowj już żadnej przeszkody ${ }^{93}$.

2. Szerszy zakres ma tu również przeszkoda powinowactwa. एrawo

88 A:AS 41 (1949) 89-119.

${ }_{89}$ Crebrae allatae sunt wyraźnie stwierdza ,...Nos autem per Apostolicas has Litteras motu proprio datas supra recensitos canones promulgamus eisdemque vim legis christifidelibus Ecclesiae Orientalis tribuimus, ubique terrarum hi sunt et tametsi Praelato diversi ritus sunt subiecti".

go Can. 49 i can. 71.

91 Can. 48.

92 Can 66 \& 2: ,In linea obliqua irritum est usque ad sextum gradum inclusive, ita tamen ut matrimonii ipedimentum toties miultiplicetur quoties communis stipes multiplicatur".

${ }_{93}$ Por. P. Pałk a Nowe prawo matżeńskie $w$ Katolickim Kościele Wschodnim, Roczniki Teologiczno-Kanoniczne 2 (1955) 199-202; J. R e$\mathrm{z}$ a c, De nova legislatione matrimoniali orientali. Orientalia Christiana Periodica 20 (1954) 384; A. S c h e u e rmann, Das Eherecht der Orientalischen Kirche. Theologische Quartalschrift, 1950, s. 423-424. 
wschodnie zna trzy rodzaje powinowactwa: jedno jak w Kościele obrządku łacińskiego wiążące jednego małżonka z krewnymi drugiego (affinitas ex digeneia I generis), drugie - wiążące krewnych jednego malżonka $z$ krewnymi drugiego (affinitas ex digeneia II generis), oraz trzecie powinowactwo powstające $w$ ściśle określonych wypadkach z zawarcia dwóch małżeństw przez osoby należące do trzech różnych rodzin (affinitas ex trigeneia) ${ }^{94}$. Przeszkodą zrywającą $w$ całym Kościele Wschodnim jest tylko pierwszy rodzaj powinowactwa we wszystkich stopniach linii prostej $i \mathrm{w}$ linii bocznej do czwartego stopnia włącznie. Dwa pozostałe rodzaje powinowactwa stanowią przeszkodę małżeńską tykko $w$ tych obrządkach wschodnich gdzie prawo partykularne ten rodzaj powinowactwa przyjmuje ${ }^{95}$. Zważywszy, że sposób obliczania pokrewieństwa ma wpływ na obliczenie powinowactwa obowiązującego W całym Kościele Wschodnim należy zauważyć, iż ten rodzaj powinowactwa nie zawsze pokrywa się $z$ zakresem tej przeszkody $w$ Kościele abrządku lacińskiego ${ }^{96}$. Ma to mianowicie miejsce przy powinowactwie czwartego stopnia linii bocznej, gdy długość szeregów jest 1-3. W tym bowiem wypadku przeszkoda powinowactwa istnieje tylko w obrządku wsschodnim ${ }^{97}$.

3. Odmienny jest równiez zakres przeszkody pokrewieństwa duchowego wywodzącego sie z chrztu (cognatio spiritualis). Przeszkoda ta w Kościele Wschodnim wiąże bowiem tylko ochrzczonego z rodzicami ahrzestynymi i rodziców chrzestnych z rodzicami naturalnymi osoby ochrzczonej ${ }^{98}$. W Kościele zaś obrządku łacińskiego przeszkoda ta istnieje między osobą ochrzczoną i jej rodzicami chrzestnymi oraz szafarzem rudzielonego chrztu ${ }^{99}$.

4. Inny wreszcie ma zakres w Kościele Wschodnim przeszkoda różności religii (disparitas cultus). O ile bowiem według prawa kodeksowego tylko osoby ochrzczone w Kościele Katolickim lub do niego nawrócone ze schizmy lub herezji nie mogą ważnie zawrzeć małżeństwa z osobą nieochrzczoną 100 to $w$ Katolickim Kościele Wschodnim każdy chrześcijanin niezdolny jest do zawarcia małżeństwa z osobą nieachrzczoną ${ }^{101}$.

B. Co do konsensu małżeńskiego. 1. W Kościele wschodnim do zawar-.

94 Can. 68. (Por. J. R e z a c, art. cyt. s. 385-387.

95 Por. P. Pałk a, Powinowactwo jako przeszkoda mazzeńska $w \mathrm{Ka}$ tolickim Kościele Wschodnim. Roczniki Teologiczno-iKanoniczne, 3 (1956) z. '1, s. 248-250.

96 Por. J. R e z a c, art. cyt. s. 387.

97 Tamize.

Can. 70 \& 2 n. 1: „Ex baptismo spiritualem cognationem contrahit patribus cum baptizato eiusque parentibus".

Fan. 768: ,Ex baptismo spiritualem cognationem contrahunt tantum cum baptisato baptisans et patrinus".

100 Kan. $1070 \S 1$.

w Can. $60 \S$ 1: „Nullum est matrimonium contractum a persona non baptisata cum persona baptizata". 
cia małeżeństwa przez pełnomocnika konieczna jest zawsze pisemna zgoda ordynariusza miejsca ${ }^{102}$. Żąda tego wprawdzie i prawo abrządku łacińskiego, lecz tylko wtedy gdy jest czas na uzyskanie takiej zgody (si tempus suppetat) ${ }^{103}$. To jest też charakterystyczne dla dyscypliny wschodniej, iż zawierający małżenstwo przez połnomocnika mają obowiązek $\mathrm{w}$ stosownym czasie razem stawic się przed kapłanem dla otrzy mania blogosławieństwa przepisanego przez księgi liturgiczne ${ }^{104}$.

2. W Kościele Wschodnim jest nieco inna redakcja przepisu określającego wpływ przymusu na skuteczność umowy małżeńskiej. O ile bowiem prawo obrządku łacińskiego w kan. 1087 \& 1 stwierdza, że przymus ciężki, niesprawiedliwy i z zewnątrz wywarty tylko wtedy powo-duje nieważność małżeństwa, gdy od niego nie można się inaczej uwolnić jak tylko przez zawarcie małżeństwa (a quo ut qui se liberet eligere cogatur matrimonium), to $w$ Kościele Wschodnim w myśl kan. 78 \& 1 taki przymus musi zmierzać wprost do wymuszenia zgođny na małżeńsitwo (ad extorquendum consensum) ${ }^{105}$. Konsekwencją podkreślonej tu różnicy jest to, iż według prawa wschodniego tyilko przymus directus seu consultus może spowodować nieważność małżeństwa podczas gdy. sformułowanie kan. $1087 \S 1$ upoważnia do wnioskowania, że ten skutek może wywołać również przymus inconsultus seu indirectus ${ }^{106}$.

3. Inne jest podejście prawa wschodniego do zatwierania małżeństw: pod warunkiem (sub conditione). Kan. 1092 Kodeksu Prawa Kanonicznego dopuszcza $w$ pewnych sytuacjach zawieranie małżeństw pod warunkiem podczas gdy kan. 83 prawa wschodniego zabrania tego stanowiąc: "Matrimonium sub conditione contrahi nequit" ${ }^{107}$.

C. Co do formy prawnej zawarcia malżeństwa. Należy zwrócić tzz. uwage na następujące osobliwości przepisów obrządku wschodniego:

1. W Kościele Wschodnim do zawarcia małżeństwa ważnego, wyjąw-

102 Can. $80 \S 1$ : "Matrimonium contrahi nequit per procuratorem, nisi' Hierarcha loci in casu singulari hanc facultatem scripto dederit".

103 Kan. 1091.

${ }_{104}$ Can. $82 \S 2 \mathrm{~W}$ związku $\mathrm{z}$ takimi małżeństwami zaznacza: „Coniuges, cum simul fuerint, benedictionem de qua in can. 91 a sacerdote a d norman horum canonum designato recipere ne negligant".

${ }_{105}$ Can. 78 \& 1: „Invalidum quoque est matrimonium initum ob vim vel metum gravem extrinsecus et iniuste incussum ad extorquendum: cansensum".

106 Por. J. Re zac, art. cyt. s. 388-389.

107 Brak jest dotąd zgodnej interpretacji tego kanonu. Kanoniści niezgodni są mianowicie co do tego, jaki skutek prawny sprowadza zakáz: kanonu 83. Jedni utrzymują, iż nie powoduje nieważności małżeństwa jakikolwiek warunek dodany do konsensu, nawet przeciwny istocie malżeństwa, gdyż należy uważać go za niedodany, druđzy, że nieważność małżeństwa sprowadza dodanie nawet warunku godziwego, inni wreszcie, że sens zakazu jest tylko taki, iż ordynariusz nie może tu nigdy zezwolić na małżeństwo warunkowe. Ta ostatnia opinia wydaje się byc najbardziej logiczna. Por. P. P a k a, Nowe prawo matzeńskie w Katolickim Kościele Wschodnim. Roczniki Teologiczno-Kanoniczne, 2 (1955) $208-210$, 
szy warunki w jakich może być stosowana forma nadzwyczajna, obok obecności świadka urzędowego i świadków zwykłych konieczne jest zawsze błogosławieństwo kapłańskie. Nie wystarcza bowiem tu, jak w obrządku lacińskim sama czynna asystencja świadka urzędowego. Wedlug bowiem kan. $85 \mathrm{z}$ motu proprio Crebrae allatae sunt małżństwo ma być zawierane $z$ towarzyszeniem obrzędu świętego (ritu sacro). ${ }^{108}$. Do spełnienia się tego wymogu wystarcza tu każde błogosławieństwo udzielone nawet $w$ jaknajogólniejszej formie, a nie koniecznie w przepisanej formie przez księgi liturgiczne ${ }^{\mathbf{1 0 9}}$.

2. W myśl obecnych przepisów Kościoła Wschodniego (kan. 86 \& 1 n. 2) proboszcz i ordynariusz miejsca na swoim terytorium mogą ważnie asystować przy małzeństwie tak swoich poddanych jak i obcych byle tylko kontrahenci byli tego samego obrządku co proboszcz lub ordynariusz będący świadkiem urzędowym (modo sint sui ritus) ${ }^{110}$. Według tych przepisów nie wystarcza więc tutaj tylko kompetencja terytorialna, jak tego wymaga kan. $1095 \S 1$ n. 2 prawa obrządku lacińskiego, gdyż konieczna jest ponadto kompetencja obrządkowa (competentia ritualis) ${ }^{111}$. W myśl poważnych autorów wystarczy jednak $w$ tym wypaidku, aby przynajmniej jeden $\mathrm{z}$ kontrahentów był tego samego obrządku co świadek urzędowy ${ }^{112}$. Wskazana tu zasada identyczności obrządku świadko urzędowego i kontrahentów dopuszcza pewne wyjątki przewidziane kan. $86 \S 3$ i to zarówno na terenach obrządku wschodniego jak i poza nimi ${ }^{113}$.

Na terenach obrzadku wschodniego wspomniany kanon zezwala na to wtedy, gdy brak jest tam w jakiejśs parafii proboszcza właściwego obrządku wschodniego. W tym wypadku ordynariusz tego obrządku może wyznaczyć duszpasterzem podległych mu wiernych proboszcza innego obrządku po uprzednim uzyskaniu zgody jego własnego ordyna-

108 Can. 85 \& 1: „Ea tantum matrimonia valida sunt quae contrahuntur ritu sacro, coram parocho, vel loci Hierarcha, vel sacerdote cui ab aliterutro facta sit facultas matrimonio assistendi et duobus saltem testibus, secundum tamen praescripta canonum qui sequutur, et salva exceptionibus de quibus in can. 89,90 ".

109 Por. P. Palka, Zwyczajna forma prawna zawarcia matżeństwa $w$ nowym ustawodawstwie Katolickiego Kościoła Wschodniego, s. 274.

110 Can. 86 \& 1: „Parochus et loci Hieracha valide matrimonio assistunt: ...2-o Intra fines dumtaxat sui territorii sive contrahentes sunt subditi, sive mon subditi, modo sint sui ritus".

111 Por. J. R e z a c, art. cyt. s. 392-393.

112 Tamże, s. 392.

113 Can. $86 \& 3, \ldots 2-0$ Deficiente parocho pro fidelibus alicuius ritus, horum Hierarcha designet alius ritus parochum, qui eorundem curam suscipiat, postquam idem Hierarcha habuerit consensum Hierarchae parochi designandi; 3-o Extra territorium proprii ritus, deficiente huius ritus Hierarcha, habendus est tamquam proprius, Hierarcha loci. Quodsi plures sint, ille habendus est tamquam proprius, quem designaverit. Sedes Apostolica vel, obtento eiusdem consensu, Patriarcha, si iure particulari cura fidelium sui ritus extra patriarchatus commorantium ei commissa est". 
irusza i ten właśnie proboszcz z samego prawa otrzymuje władzę do ważnego asystowania przy małżeństwach wiernych obrządku wschodniego.

Poza terenem obrządku wschodniego, tj. tam gdzie brak jest ordynariusza własnego obrządku wschodniego, ordynariuszem wiernych obrządku wschodniego jest miejscowy ordynariusz innego obrządku ${ }^{114}$. On wyznacza im duszpasterza, który również z samego prawa ważnie asystuje przy zawieraniu małżeństw wiernych obrząaku wschodniego. Taka sytuacja może mieć miejsce dość często na naszych terenach.

Należy tu wreszcie zaznaczyć, że wspornniany wymóg identyczności obrządku świadka urzędowego i kontrahentów odnosi się nie tylko do proboszczów obrządku wschodniego, lecz także i łacińskiego. Wyraźnie orzekla tak Papieska Komisja do zredagowania Kodeksu Prawa Kanonicznego dla Kościoła Wschodniego $5 \mathrm{~V} 1953 \mathrm{r}$. w swej odpowiedzi na przedłożoną jej $w$ tej sprawie wątpliwośćc ${ }^{115}$.

3. Mając na uwadze uznawaną dziś w Kościele równą godność wszystkich obrządków należy przyjąć, iź od wejścia w życie motu proprio Crebrae allatae sunt stracił swą moc wiążąca kan. 1099 \& 1 n. 3 zobowiązujący osoby obrząăku wschodniego zawierające małżeństwo z łacinnikami do zawierania małżeństwa według formy prawnej kodeksowej. Obecnie małżeństwa takie moga być zawierane ważnie zarówiıo wedlug formy przyjętej przez prawo łacińskie jak i wschodnie ${ }^{116}$. Jeüłynie do godziwości konieczną jest rzeczą, aby były zawierane „ritu viri et coram ejusdem parocho" jak tego wymaga prawo obrządku wschodniego w kanonie $88 \S 3$. W obrządku narzeczonej małżeństwa takie mogłyby być zawierane jedynie wtedy, gdyby narzeczony mający stałe lub tymczasowe zamieszkanie na terenach wschodnich (in regione orientali) wyraził zgođę na małzeństwo wobec proboszcza narzeczonej 117 .

Należałoby wreszcie zaznaczyć, że obecnie przy zawieraniu małżeństw przez katolików obrządku wschodniego ${ }^{118}$, pođobnie jak i łacińskiego ${ }^{119}$, $z$ akatolikami ochrzczonymi obrządku wschodniego zachowanie katolickiej formy prawnej konieczne jest jedynie do godziwości a nie waź-

114 Por. J. R e z a c, art. cyt. s. 395-396.

115 AAS 45 (1953) 313: „D. - An verba can. 86 \& 1, 2: ,sive contrahentes sunt subditi, sive non subditi, modo sint sui ritus", collata cum verbis can. $1095 \S 1$ n. 2 C.J.C.: ,in quo (territorio) matrimoniis nedum suorum subditorum, sed etiam non subditorum valide assistunt", ita intelligenda sint ut parochus et loci Hierarcha orientalis ritus valeant valide assistere matrimonio duorum fidelium latini ritus, itemque ut parochus et loci Hierarcha latini ritus valide assistere valeant matrimonio duorum fidelium orientalis ritus. R. Negative".

116 Por. J. Rez a c, art. cyt. s. 401.

117 Can. 88 \& 3.

118 Orientalium Ecclesiarum, n. 18.

119 Motu proprio Paw 1 a VI Matrimonia mixta z 31 III 1970. AAS 62 (1970) 257-262. Por. P. P a $₫ \mathrm{k}$ a, Forma prawna zawarcia matżéstw mieszanych. Roczniki Teologiczno-Kanoniczne 18 (1971) z. 5 s. 13. 
ności małżeństw, jak tego domagał się kan. 1094 Kodeksu Prawa Kanonicznego oraz motu proprio Crebrae allatae sunt $\mathrm{w}$ kan. 85120.

W traktacie De locis et temporibus sacris należy podkreślić, iż prawo Kościołów Wschodnich zna $\mathrm{w}$ zasadzie tylko świątynie $\mathrm{z}$ jednym ołtarzem. Należy też tu wskazać jakie zachodzą różnice między dyscypliną obrządku wschodniego i lacińskiego odnośnie postów i świąt, który każdy wierny ma obowiązek zachowywać zgodnie ze swoim obrządkiem ${ }^{121 .}$ Jedynie przebywający poza obszarem lub terytorium własnego obrządku co do świąt mogą w pelni stosować się do przepisów obowiązujących w miejscu ich pobytu. Członkowie zaś rodzin należący do różnych obrządków w zachowaniu świąt i postów mogą stosować się do jednego i tego samego obrządku ${ }^{122}$. Winno się też tu wskazać na różnicę czasową $w$ obchodzeniu różnych świąt $z$ racji nadal przestrzegania przez niektore Kościoły wschodnie kalendarza juliańskiego ${ }^{123}$, a nie gregoriańskiego, jak to jest $w$ obrządku lacińskim.

Przy omawianiu traktatu De cultu divino należy wyjaśnić jakie zasady winny być przestrzegane przez wiernych obrządku wschodniego gdy chodzi o communicatio in sacris za katolikami wschodniego obrządku ${ }^{124}$.

\section{Problem of Teaching the Law of Catholic Oriental Churches in the theological Seminaries of Latin Rite}

\section{SUMMARY}

At the outset the author points to the ground of the differences which exist between the rules of law of the Latin Church Rite and the Oriental one. The author also underlines the need to acquant alumnes of our theological Seminaries with some rules of the Oriental Catholic Churches.

Among the different reasons which appeal for advisability of this subject the author points among other things to the fact that there live on the Polish areas some numbers of the worshippers of Oriental rite who avail temselves of religius service of priests of Latin rite. The warshipper of Oriental rite in principle should to comply to rules of his own rite. The rules of Oriental rite in some details sometimes differ from the law of Latin rite. Therefore alumnus as the future priest

120 Por. P. $\mathrm{Pa} \mathrm{ka}$, Nowe prauo matżeńskie $w$ Katolickim Kościele Wschodnim, Roczniki Teologiczno-Kanoniczne 2 (1955) 211-218.

${ }^{121}$ Dyscyplina postu $w$ Kościolach Wschodnich jest bardziej surowa niż u łacinników. Por. Acta et Decreta Synodi Provincialius Ruthenorum Galiciae habitae Leopoli an. 1891, Romae 1896 Titulus XI De Teiuniis.

122 Orientalium Ecclesiarum, n. 21.

123 Por. A. Petra ni, dz. cyt. s. 101-106; B. Emmi, dz. cyt. s. 17.

124 Orientalium Ecclesiarum, n. 24-29. Por. P. T o c a n e 1, Lo studio del Diritto canonico orientale. Seminarium. Nova Series: Anno XV-N.4: 1975, s. 899; Secretariatus ad christianorum unionem fovendam, Directorium, pars prima, d. 14 maii 1967. 
should be instructed about those differences chiefly in fields which concern the priestly work.

In the further reasonings the author confronts the rules of law of Latin Church Rite with obligatory law of Catholic Oriental Churches. At the same time author indicates a number of differences which the priests of Latin rite ought to know as something useful and even indispensable. This sort of differences become notceable especially in the law "De personis" and in the treaty "De matrimonio". In the last case relatively much attention was given to display the differences in the section of the impediment of marriage and canonical form of marriage. 